\title{
Assessment of the presence of a dominant follicle and selection of dairy cows suitable for superovulation by a single ultrasound examination
}

\author{
L. Bungartz and H. Niemann* \\ Institut für Tierzucht und Tierverhalten (FAL), Mariensee, 31535 Neustadt, Germany
}

The physiological significance of the dominant follicle $(>9 \mathrm{~mm}$ in diameter in a growing phase; stable for $<3$ days) for the superovulatory response in 117 lactating Holstein Friesian dairy cows was investigated. The presence or absence of a dominant follicle was determined retrospectively by analysing videotapes of follicular growth in all the ovaries. Superovulation was induced by $28 \mathrm{mg}$ Armour units (400 mg NIH-FSH-P1) of FSH (Folltropin ${ }^{(i i}$ ) administered either twice or once a day i.m. over 4 days in a decreasing regimen or as a single injection s.c. Donors were scanned daily from day 3 after the oestrus preceding superovulation until embryo recovery. In Expt 1 donors superovulated (two times a day for 4 days) in the absence of a dominant follicle yielded more corpora lutea (I1.7 \pm 0.9 versus $4.7 \pm 1.1, P<0.01)$, ova and embryos $(8.2 \pm 1.2$ versus $2.8 \pm 1.0, P<0.01)$ and transferable embryos $(5.0 \pm 1.0$ versus $2.1 \pm 0.9, P<0.05)$ compared with donors treated in the presence of a dominant follicle. In Expts 2 and 3 donors were scanned only on the day of superovulation and donors with $<10$ follicles $3-8 \mathrm{~mm}$ in diameter were considered to have a dominant follicle, while donors with $\geqslant 10$ small follicles $3-8 \mathrm{~mm}$ in diameter were classified as having no dominant follicle. In Expt 2 donors superovulated (once a day for 4 days) in the absence of a dominant follicle yielded more corpora lutea (15.5 \pm 2.5 versus $4.5 \pm 1.4, P<0.01$ ), ova and embryos (12.9 \pm 2.8 versus $1.2 \pm 0.4, P<0.01$ ) and transferable embryos $(7.8 \pm 2.5$ versus $0.3 \pm 0.2, P<0.01)$ compared with donors treated in the presence of a dominant follicle. In Expt 3 donors superovulated (single s.c. injection) in the absence of a dominant follicle yielded more corpora lutea (11.2 \pm 2.7 versus $1.9 \pm 0.8, P<0.01$ ), ova and embryos $(9.5 \pm 2.7$ versus $1.2 \pm 0.6, P<0.01)$ and transferable embryos $(3.4 \pm 1.3$ versus $0.3 \pm 0.2, P<0.05$ ) compared with donors treated in the presence of a dominant follicle. In Expt 4 donors were superovulated using one injection of FSH per day for 4 days and scanned four times at intervals of 2 days. In the absence of a dominant follicle donors yielded more corpora lutea $(19.3 \pm 2.3$ versus $7.7 \pm 1.6, P<0.01)$, ova and embryos (17.4 \pm 2.6 versus $5.1 \pm 1.4, P<0.01$ ) and transferable embryos $(10.3 \pm 2.2$ versus $1.0 \pm 0.5$, $P<0.01$ ) than in the presence of a dominant follicle. In cows in which the dominant follicle had been aspirated under sonographical control 2 days before superovulation, the superovulatory response was similar to that in animals treated in the absence of a dominant follicle, and was significantly enhanced compared with animals superovulated in the presence of a dominant follicle (21.6 \pm 2.2 corpora lutea, $18.7 \pm 12.7$ ova and embryos, $10.1 \pm 1.5$ transferable embryos). The major conclusions from this investigation are: (1) that the presence or absence of a dominant follicle can be detected by a minimized ultrasound scanning schedule using the number of small follicles as the major criterion; ( 2 ) the presence or absence of a dominant follicle significantly affects superovulatory responses in dairy cattle; and (3) ultrasound-guided follicular aspiration of the dominant follicle provides an accurate and reliable procedure to increase ovarian responses in dairy cattle possessing a dominant follicle. 


\section{Introduction}

Endocrinological and ultrasonographical studies have demonstrated that follicular growth during the bovine oestrous cycle occurs in two or three waves. During each wave of follicular growth, a dominant follicle develops that suppresses the growth of other smaller follicles. The dominant follicle that develops during the last wave of each oestrous cycle undergoes ovulation (Ireland and Roche, 1987; Sirois and Fortune, 1988; Knopf et al., 1989; Savio et al., 1988, 1990a). Recent reports suggest that the presence or absence of a dominant follicle can affect the superovulatory responses in cattle. A daily ultrasound examination schedule has been used to demonstrate that superovulatory responses are reduced in animals treated in the presence of a dominant follicle compared with animals without a dominant follicle at the onset of the superovulatory treatment (Guilbault et al., 1991; Huhtinen et al., 1992). Preliminary evidence suggested that a single ultrasound examination could not accurately diagnose the presence or absence of a dominant follicle and that no effects on the superovulatory responses were found (Wilson et al, 1990). In addition, the superovulatory response was reduced following injections of steroid-free bovine follicular fluid or when the superovulatory response was initiated at the end of the oestrous cycle in the presence of a dominant follicle (Pierson and Ginther, 1988; Lussier and Carruthers, 1989; Gray et al. 1992).

Frequent injections of FSH have been shown to be required to achieve satisfactory ovarian responses in cattle (Elsden et al., 1978). The superovulatory response has been found to be higher following injections given twice a day i.m. over 4 days compared with injections given once a day (Chupin and Procureur, 1982, 1983; Walsh et al., 1993). Furthermore, it has been suggested that a single injection s.c. of the total dosage of FSH would be a simplified and successful superovulatory treatment in beef cattle (Bo et al., 1991a; Hockley et al., 1992).

The primary goal of the present study was to test the hypothesis that the number of small subordinate follicles in a wave of follicular growth can be used as a simple criterion for the presence or absence of a dominant follicle, which can then be assessed by a less frequent ultrasound examination schedule. The second main aim was to explore the suitability of ultrasound-guided follicular aspiration to remove the dominant follicle and to determine whether this would improve the superovulatory responses. A series of experiments was conducted in which the ultrasound examination frequency was reduced to determine the presence or absence of a dominant follicle, and the effects on superovulatory treatment were observed after less frequent injections of FSH.

\section{Materials and Methods}

\section{Animals}

A total of 142 Holstein Friesian dairy cows $(4.0 \pm 0.1$ years of age) (from the experimental herds of the Institute) of which 117 were superovulated, were used 12 weeks postpartum for these experiments. The animals were in lactation $1-6$ (average $2.2 \pm 0.1$ lactations) and yielded an average of $5300 \mathrm{~kg}$ milk with $4.3 \%$ fat. All animals underwent regular systematic gynaecological examinations during the postpartum period, and only healthy cows with spontaneous oestrus 6-8 weeks postpartum were included in this study. The cows were checked for oestrus twice a day at $12 \mathrm{~h}$ intervals by trained personnel.

\section{Ultrasound examination schedule}

Ultrasound examinations were performed using the Picker CS 9000 ultrasound machine (Picker, Hannover), with a $5 \mathrm{MHz}$ linear probe (EUP-033J, Hitachi, Hannover) for rectal investigations and a $6.5 \mathrm{MHz}$ fingertip probe (EUP-F-33I, Hitachi, Hannover) for the follicular puncture experiment, providing a resolution limit of approximately $1 \mathrm{~mm}$. Ovaries were examined with the rectal probe from medial to lateral and cranial to caudal every $24 \mathrm{~h}$ in the same manner. All ultrasound examinations were recorded on videotape (Blaupunkt, RTV-915, EGC) for retrospective analysis, which was carried out without knowing the results of the superovulatory treatment. Similarly, follicular growth on each ovary over the whole observation period was measured on the screen of the ultrasound machine. Daily ultrasound examinations were conducted in Expt 1 (26 cows) starting on the third day after oestrus up to embryo recovery to identify the dominant follicle based on growth and size. A follicle was categorized as dominant if it had a diameter of $9 \mathrm{~mm}$ in a growing phase or for $<3$ days in a plateau phase.

In Expts 2 and 3 ( 26 and 27 cows, respectively) ovaries were examined by ultrasound only on the days of superovulatory induction and embryo recovery. The criterion for the presence or absence of a dominant follicle on the day of superovulatory induction was the number of small follicles $3-8 \mathrm{~mm}$ in diameter. Animals with more than ten follicles in this category (on both ovaries) were evaluated as being without a dominant follicle and animals with fewer than ten follicles $3-8 \mathrm{~mm}$ in diameter were evaluated as having a dominant follicle. This criterion had been derived from previous experiments (L. Bungartz and H. Niemann, unpublished).

In Expt 4 (38 cows) ovaries were examined by ultrasonography $10,8,6,4$ and 2 days before onset of superovulation and on day 7 after superovulatory oestrus at embryo recovery. In 13 animals of this group the dominant follicle was aspirated $48 \mathrm{~h}$ before the onset of superovulatory treatment. These animals underwent an epidural anaesthesia and the $6.5 \mathrm{MHz}$ fingertip probe connected with a $62 \mathrm{~cm}$ carrier was forwarded into the vagina to visualize the ovaries and the ultrasound-guided aspiration needle. The disposable aspiration needle was inserted into the dominant follicle of the rectally fixed ovary after penetration of the vaginal wall; follicular fluid was aspirated at $400 \mathrm{mg} \mathrm{Hg}$ pressure (Fig. I) and checked for the presence of an oocyte at a magnification of $\times 100$.

\section{Corpus luteum diameter and analysis of progesterone}

As it had been shown that the presence of a functional corpus luteum and, therefore, high progesterone concentrations 

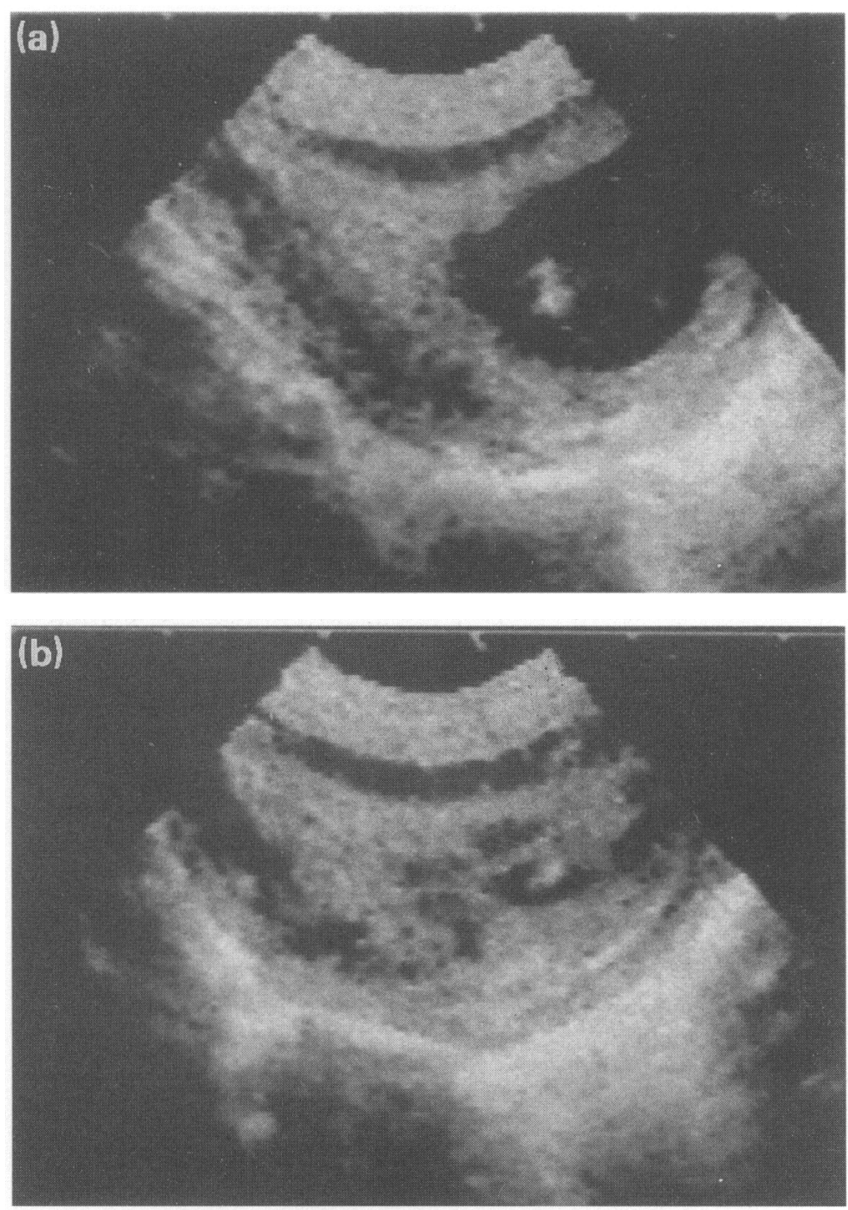

Fig. 1. Ultrasonographical images of a dominant follicle in a cow before and after ultrasound-guided aspiration of follicular contents. (a) Dominant follicle immediately before transvaginal ultrasound-guided aspiration, 2 days before onset of superovulatory treatment. (b) Dominant follicle immediately after puncture of the follicular wall and aspiration of follicular fluid. The follicle has collapsed and the lumen has disappeared.

affect the superovulatory response (Yadav et al., 1986; Goto et al., 1988; Herrler et al., 1990), the growth of the corpus luteum was monitored ultrasonically and the progesterone concentrations were determined. From the third day after oestrus until midcycle and the onset of superovulatory treatment, the growth of the corpus luteum was observed. In Expt 1 the diameter of the corpus luteum was measured on the screen of the ultrasound machine and in an additional 25 cows that were not superovulated for this study. In all these 51 animals milk samples were collected every $48 \mathrm{~h}$ from the third day after oestrus until superovulation. In the other experiments the progesterone concentrations in milk samples were determined only at the onset of the superovulatory treatment. The progesterone concentrations were determined using an enzymeimmunoassay (Van de Wiel and Koops, 1986). The lowest concentration of progesterone detected was $\mathrm{Ing} \mathrm{ml}^{-1}$. The intra-assay coefficient of variation was $12.2 \%$ and all samples were analysed in one assay. The crossreactions with 17-hydroxyprogesterone, oestradiol and cortisol were 0.005 , $<0.002$ and $0.1 \%$, respectively.

\section{Superovulatory treatment and embryo recovery}

Superovulation was induced in 117 cows between days 9 and 13 of the oestrous cycle using FSH-P (Folltropin ${ }^{(m)}$ : Vetrepharm, London, Ontario; batch number 165-60) at a total dose of $28 \mathrm{mg}$ Armour units (equivalent to $400 \mathrm{mg} \mathrm{NIH-}$ FSH-P1 standard) per animal. FSH-P was administered twice a day $(2 \times 6 \mathrm{mg}, 2 \times 4 \mathrm{mg}, 2 \times 3 \mathrm{mg}$ and $2 \times 1 \mathrm{mg}$ Armour units) i.m. in Expt 1 and once a day (12, 8, 5, 3 mg Armour units) i.m. in Expts 2 and 4 over 4 days in a decreasing regimen. In Expt 3 the animals received the total dose as a single injection s.c. All injections i.m. were performed in the muscle semitendinosus and injections s.c. were inserted behind the shoulder.

Regression of the corpora lutea in all animals was induced by administering a total of $526 \mu \mathrm{g}$ Cloprostenol (Estrumate ${ }^{\circledR}$ : Pitman-Moore, Burgwedel) $48 \mathrm{~h}$ after the first FSH injection. All animals were observed in oestrus $48 \mathrm{~h}$ later and were inseminated twice within $12 \mathrm{~h}$ with semen of proven fertility. Seven days after the first insemination, ovarian responses (number of corpora lutea and nonovulated follicles $>12 \mathrm{~mm}$ ) were determined by ultrasound examination. The uterine horns were flushed nonsurgically using $300 \mathrm{ml}$ PBS supplemented with $1 \%$ new-born calf serum. After a sedimentation period of $15 \mathrm{~min}$, ova and embryos were searched at magnifications of $\times 12$ and $\times 50$, evaluated according to morphological criteria at magnifications of $\times 50$ and $\times 100$, and classified into four groups (excellent, good, degenerated embryos, unfertilized ova) (Niemann, 1986). Morulae and blastocysts in the 'excellent' and 'good' categories were evaluated as being transferable.

The superovulatory treatment schedules, the respective ultrasound examination schedules and the milk progesterone collection schedule for each experiment are shown (Table 1).

\section{Statistical analyses}

All data are presented as means \pm SEM. Data were analysed by analysis of variance and differences between groups (with or without a dominant follicle) were calculated by Student's $t$ test in Expts 1, 2 and 3 and by Tukey's test in Expt 4. Differences were considered to be significant at $P<0.05$. The correlation coefficient between the concentration of progesterone and the diameter of corpora lutea was calculated according to Pearson (SAS).

\section{Results}

\section{General observations}

From 51 cows scanned daily to determine the presence and growth of the dominant follicle, 22 animals were superovulated when the dominant follicle displayed linear growth and had not yet reached the plateau phase. Starting on day 10 before superovulation, an average diameter of $6.0 \pm 1.1 \mathrm{~mm}$ was measured that increased to $8.0 \pm 1.2 \mathrm{~mm}$ on day 9 , $10.2 \pm 1.2 \mathrm{~mm}$ on day $8, \quad 12.3 \pm 1.2 \mathrm{~mm}$ on day 7 , $14.9 \pm 1.1 \mathrm{~mm}$ on day $6,16.8 \pm 1.0 \mathrm{~mm}$ on day 5 and finally to $18.9 \pm 0.9 \mathrm{~mm}$ on day 4 before superovulation. In the remaining 29 cows, the large follicle had an average diameter of 
Table 1. Overview of the number of cows, superovulatory treatment schedule, ultrasound examination schedule, and milk progesterone sampling in the four experiments of this study

\begin{tabular}{|c|c|c|c|c|}
\hline Characteristic & Experiment 1 & Experiment 2 & Experiment 3 & Experiment 4 \\
\hline Number of animals & 26 & 26 & 27 & 38 \\
\hline $\begin{array}{l}\mathrm{FSH}(400 \mathrm{mg}) \\
\text { treatment schedule }{ }^{\mathrm{a}}\end{array}$ & $2 \times$ Daily i.m., 4 days & $1 \times$ Daily i.m., 4 days & Single injection s.c. & $1 \times$ Daily i.m., 4 days \\
\hline Ultrasound examinations & $\begin{array}{c}\text { Starting } 3 \text { days after } \\
\text { oestrus daily to } \\
\text { embryo recovery }\end{array}$ & $\begin{array}{l}\text { On days of } \\
\text { superovulation }^{b} \text { and } \\
\text { embryo recovery }\end{array}$ & $\begin{array}{l}\text { On days of } \\
\text { superovulation }^{b} \text { and } \\
\text { embryo recovery }\end{array}$ & $\begin{array}{l}\text { On days } 10,8,6,4, \\
\text { and } 2^{c} \text { before } \\
\text { superovulation and } \\
\text { day of embryo } \\
\text { recovery }\end{array}$ \\
\hline Milk progesterone samples & $\begin{array}{l}\text { Every } 2 \text { days up to day } \\
\text { of superovulation }\end{array}$ & Day of superovulation & Day of superovulation & Day of superovulation \\
\hline
\end{tabular}

\footnotetext{
${ }^{a}$ Decreasing regimen

b $<10$ follicles $3-8 \mathrm{~mm}$ in diameter (dominant follicle present); $\geqslant 10$ follicles $3-8 \mathrm{~mm}$ in diameter (dominant follicle absent).

'Aspiration of the dominant follicle $48 \mathrm{~h}$ before superovulation $(n=13)$.
}

Table 2. Progesterone concentrations of milk and average diameter of corpus luteum in relation to the presence $(+)$ or absence $(-)$ of a dominant follicle at the time of superovulatory induction in cows

\begin{tabular}{|c|c|c|c|c|}
\hline Experiment & $\begin{array}{l}\text { Progesterone } \\
\left(\mathrm{ng} \mathrm{ml} \mathrm{ml}^{-1}\right) \\
-\end{array}$ & $\begin{array}{l}\text { Corpus luteum diameter } \\
\qquad(\mathrm{mm}) \\
-\end{array}$ & 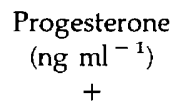 & $\begin{array}{l}\text { Corpus luteum diameter } \\
\qquad \begin{array}{c}(\mathrm{mm}) \\
+\end{array}\end{array}$ \\
\hline I & $18.1 \pm 2.2$ & $39.5 \pm 1.3$ & $15.9 \pm 2.5$ & $41.1 \pm 1.5$ \\
\hline 2 & $17.0 \pm 1.2$ & $40.2 \pm 1.1$ & $17.0 \pm 2.8$ & $37.0 \pm 1.5$ \\
\hline 3 & $15.7 \pm 2.2$ & $39.8 \pm 1.3$ & $14.6 \pm 2.1$ & $37.2 \pm 1.5$ \\
\hline 4 & $20.2 \pm 2.2$ & $40.6 \pm 0.7$ & $15.7 \pm 7.2$ & $41.1 \pm 2.2$ \\
\hline
\end{tabular}

Values are mean \pm SEM.

$15.1 \pm 0.7 \mathrm{~mm}$ on day 10 before superovulation, which increased slightly to $17.6 \pm 0.6 \mathrm{~mm}$ on day $9,19.8 \pm 0.6 \mathrm{~mm}$ on day 7 before superovulation and then to $21.2 \pm 0.5 \mathrm{~mm}$ on day 6 before superovulation and finally started to decline to $20.4 \pm 0.5 \mathrm{~mm}$ on day 4 before superovulatory induction.

Progesterone concentrations in milk and the average diameter of the corpus luteum as measured by ultrasound at the time of superovulatory induction were similar in animals with or without a dominant follicle (Table 2). The corpus luteum was detected as a dark area on the ovary and the average diameter on day 3 after oestrus was $22.0 \pm 5.4 \mathrm{~mm}$, which increased to $38.7 \pm 5.1 \mathrm{~mm}$ at the time of superovulatory induction. Milk progesterone concentrations as determined from milk samples taken every $48 \mathrm{~h}$ increased from $2.4 \pm 2.3 \mathrm{ng} \mathrm{ml}^{-1}$ on the third day after oestrus to $15.5 \pm 7.6 \mathrm{ng} \mathrm{ml}^{-1}$ on the day of superovulatory induction. Milk progesterone concentrations and the average diameter of the corpus luteum on the respective days were closely correlated $(P<0.05)$ on days $3(r=0.4), 5(r=0.6)$, $7(r=0.4)$ and $9(r=0.4)$ before superovulation as well as on the day of superovulatory induction $(r=0.4)$.

\section{Experiment 1}

In the first experiment, ovaries were examined by daily ultrasound examination, and the growth pattern and the physiological significance of the dominant follicle for the superovulatory response were elucidated using conventional FSH treatment. It was found that nine of the 26 cows possessed a dominant follicle in the linear growth phase while in 17 animals no dominant follicle could be detected. The ovarian response was significantly increased in animals superovulated in the absence of a dominant follicle (Table 3). The number of degenerated embryos, unfertilized ova and nonovulated follicles $(>12 \mathrm{~mm})$ was not different between the two groups.

\section{Experiment 2}

In Expts 2 and 3 ovaries were examined only on the day of superovulatory treatment to assess the number of small (3-8 mm) follicles in response to a daily FSH injection over a period of 4 days. A single ultrasound examination at the time of superovulatory induction allowed the number of small follicles 3-8 $\mathrm{mm}$ in diameter to be counted. Twelve of the 26 cows in this experiment were categorized as having a dominant follicle, as indicated by $<10$ follicles $3-8 \mathrm{~mm}$ in diameter, while 14 animals did not possess a dominant follicle. The ovarian response was significantly enhanced when animals were superovulated in the absence of a dominant follicle compared with animals superovulated in the presence of a 
Table 3. Ovarian responses and embryo yields in cows following FSH injections given twice a day over 4 days and daily ultrasound scanning to determine the presence or absence of a dominant follicle at the time of superovulatory induction (Expt 1)

\begin{tabular}{lcc}
\hline & \multicolumn{2}{c}{ Dominant follicle } \\
\cline { 2 - 3 } Characteristic & + & - \\
& & \\
\hline Number of animals & 9 & 17 \\
Number of corpora lutea & $4.7 \pm 1.1^{\mathrm{a}}$ & $11.7 \pm 0.9^{\mathrm{b}}$ \\
Number of ova and embryos & $2.8 \pm 1.0^{\mathrm{a}}$ & $8.2 \pm 1.2^{\mathrm{b}}$ \\
Recovery rate (\%) (ova and & 59.5 & 69.8 \\
$\quad$ embryos/corpora lutea) & & \\
Number of fertilized ova & $2.4 \pm 1.0^{\mathrm{c}}$ & $5.4 \pm 1.0^{\mathrm{d}}$ \\
Fertilization rate (\%) & 88.0 & 66.2 \\
Number of transferable embryos & $2.1 \pm 0.9^{\mathrm{c}}$ & $5.0 \pm 1.0^{\mathrm{d}}$ \\
Transferable embryos/total & 76.0 & 61.2 \\
$\quad$ ova and embryos (\%) & & \\
Transferable embryos/fertilized ova (\%) & 86.4 & 92.4 \\
& & \\
\hline
\end{tabular}

Values are means \pm SEM.

${ }^{a, b}$ Values with different superscripts are significantly different $(P<0.01)$.

${ }^{c}$ Values with different superscripts are significantly different $(P<0.05)$.

Table 4. Ovarian responses and embryo yields in cows following FSH injections given once a day over 4 days and a single ultrasound examination to determine the presence or absence of a dominant follicle at the time of superovulatory induction (Expt 2)

\begin{tabular}{lcc}
\hline & \multicolumn{2}{c}{ Dominant follicle } \\
\cline { 2 - 3 } Characteristic & + & - \\
\hline Number of animals & 12 & 14 \\
Number of corpora lutea & $4.5 \pm 1.4^{\mathrm{a}}$ & $15.5 \pm 2.5^{\mathrm{b}}$ \\
Number of ova and embryos & $1.2 \pm 0.4^{\mathrm{a}}$ & $12.9 \pm 2.8^{\mathrm{b}}$ \\
Recovery rate (\%) (ova and & 26.0 & 83.4 \\
$\quad$ embryos/corpora lutea) & & \\
Number of fertilized ova & $0.5 \pm 0.2^{\mathrm{a}}$ & $8.3 \pm 2.5^{\mathrm{b}}$ \\
Fertilization rate (\%) & 42.9 & 64.1 \\
Number of transferable embryos & $0.3 \pm 0.2^{\mathrm{a}}$ & $7.8 \pm 2.5^{\mathrm{b}}$ \\
Transferable embryos/total & 28.6 & 60.2 \\
$\quad$ ova and embryos (\%) & & \\
Transferable embryos/fertilized ova (\%) & 66.7 & 94.0 \\
& & \\
\hline
\end{tabular}

Values are means \pm SEM.

${ }^{a, b}$ Values with different superscripts are significantly different $(P<0.01)$.

dominant follicle (Table 4). The numbers of degenerated embryos, unfertilized ova and follicles $>12 \mathrm{~mm}$ were not different between the two groups.

\section{Experiment 3}

In this experiment a single ultrasound examination was made as in Expt 2, while the animals were treated with a single FSH injection s.c. Fifteen out of 27 cows were found to have a dominant follicle, while 12 cows were categorized as having no
Table 5. Ovarian responses and embryo yields in cows following a single FSH injection s.c. and a single ultrasound examination to determine the presence or absence of a dominant follicle at the time of superovulatory induction (Expt 3)

\begin{tabular}{lcc}
\hline & \multicolumn{2}{c}{ Dominant follicle } \\
\cline { 2 - 3 } Characteristic & + & - \\
\hline Number of animals & 15 & 12 \\
Number of corpora lutea & $1.9 \pm 0.8^{\mathrm{a}}$ & $11.2 \pm 2.7^{\mathrm{b}}$ \\
Number of ova and embryos & $1.2 \pm 0.6^{\mathrm{a}}$ & $9.5 \pm 2.7^{\mathrm{b}}$ \\
Recovery rate (\%) (ova and & 62.1 & 85.1 \\
$\quad$ embryos/corpora lutea) & & \\
Number of fertilized ova & $0.7 \pm 0.4^{\mathrm{c}}$ & $5.8 \pm 1.9^{\mathrm{d}}$ \\
Fertilization rate (\%) & 61.1 & 60.5 \\
Number of transferable embryos & $0.3 \pm 0.2^{\mathrm{c}}$ & $3.4 \pm 1.3^{\mathrm{d}}$ \\
Transferable embryos/total & 27.8 & 36.0 \\
$\quad$ ova and embryos (\%) & & \\
Transferable embryos/fertilized ova (\%) & 45.5 & 59.4 \\
& & \\
\hline
\end{tabular}

Values are means \pm SEM

a,b Values with different superscripts are significantly different $(P<0.01)$.

${ }^{\mathrm{c}, \mathrm{d}}$ Values with different superscripts are significantly different $(P<0.05)$.

dominant follicle based on the number of small follicles 3-8 $\mathrm{mm}$ in diameter. The ovarian response in animals superovulated in the presence of a dominant follicle was significantly reduced compared with animals superovulated in the absence of a dominant follicle (Table 5). The numbers of degenerated embryos, unfertilized ova and follicles $>12 \mathrm{~mm}$ were not different between the two groups.

\section{Experiment 4}

In the final experiment, ovaries were examined every second day before superovulation, and the dominant follicle was removed by ultrasound-guided aspiration. On the basis of results from the preceding experiments, the animals were superovulated as in Expt 2. Ultrasound examinations at intervals of 2 days allowed the dynamics of the dominant follicle to be detected. Fourteen of the 38 cows had no dominant follicle at the time of superovulatory induction, while in 24 animals a dominant follicle could be detected. In 13 of these 24 animals the follicle was aspirated $48 \mathrm{~h}$ before superovulatory treatment. The ovarian response was significantly enhanced when animals were superovulated in the absence of a dominant follicle compared with animals superovulated in the presence of a dominant follicle. Aspiration of the dominant follicle increased ovarian responses to those of animals superovulated in the absence of a dominant follicle. Both sets of values were therefore significantly higher than in animals superovulated in the presence of a dominant follicle (Table 6). Oocytes were found in the follicular fluid of 8 of the 13 donors $(61.5 \%)$ in which the dominant follicle had been aspirated. The numbers of degenerated embryos, unfertilized ova and follicles $>12 \mathrm{~mm}$ were not different among the three groups. 
Table 6. Ovarian responses and embryo yields in cows following FSH injections once a day over 4 days and four ultrasound examinations to determine the presence or absence of a dominant follicle and its aspiration 2 days before superovulation (Expt 4)

\begin{tabular}{|c|c|c|c|}
\hline \multirow[b]{2}{*}{ Characteristic } & \multicolumn{2}{|c|}{ Dominant follicle } & \multirow[b]{2}{*}{ Aspiration } \\
\hline & + & - & \\
\hline Number of animals & 11 & 14 & 13 \\
\hline Number of corpora lutea & $7.7 \pm 1.6^{\mathrm{a}}$ & $19.3 \pm 2.3^{\mathrm{b}}$ & $21.6 \pm 2.2^{\mathrm{b}}$ \\
\hline Number of ova and embryos & $5.1 \pm 1.4^{\mathrm{a}}$ & $17.4 \pm 2.6^{\mathrm{b}}$ & $18.7 \pm 2.7^{b}$ \\
\hline Recovery rate (\%) (ova and embryos/corpora lutea) & 65.9 & 90.4 & 86.8 \\
\hline Number of fertilized ova & $2.4 \pm 0.8^{\mathrm{a}}$ & $12.6 \pm 2.5^{\mathrm{b}}$ & $12.9 \pm 1.7^{b}$ \\
\hline Fertilization rate $(\%)$ & 46.4 & 72.1 & 69.1 \\
\hline Number of transferable embryos & $1.0 \pm 0.5^{\mathrm{a}}$ & $10.3 \pm 2.2^{\mathrm{b}}$ & $10.1 \pm 1.5^{\mathrm{b}}$ \\
\hline Transferable embryos/total ova and embryos (\%) & 19.6 & 59.0 & 53.9 \\
\hline Transferable embryos/fertilized ova $(\%)$ & 42.3 & 81.8 & 78.0 \\
\hline
\end{tabular}

Values are means $\pm \mathrm{SEM}$.

${ }^{a, b}$ Values with different superscripts are significantly different $(P<0.01)$.

\section{Discussion}

Results from this investigation showed that under the conditions of our experiments the presence or absence of a dominant follicle at the time of superovulatory induction has profound effects on the ovarian response in lactating dairy cattle, and that the presence or absence of the dominant follicle can be used as an appropriate criterion to predict the ovarian response upon superovulation. Confounding effects from the different schedules for FSH injection can be ruled out, since the suppressing effects of the dominant follicle on the superovulatory response were consistently found in all experiments. The same holds true for the different scanning intensities, since ultrasound is known not to affect follicular growth and development (Sirois and Fortune, 1988).

A growing dominant follicle displays linear growth during the selection phase and after it has grown to approximately $9 \mathrm{~mm}$ in diameter inhibits the growth of all smaller subordinate follicles (Pierson and Ginther, 1988; Sirois and Fortune, 1988; Guilbault et al., 1991). The dominant follicle is considered to be morphologically and functionally dominant (Lavoir and Fortune, 1990) and reaches a plateau in growth after a second growth period (Sirois and Fortune, 1988; Grasso et al., 1989a). During this second period of growth the dominant follicle can be induced to ovulate by prostaglandin-induced luteolysis (Kastelic et al., 1990; Savio et al., 1990b; Driancourt et al., 1991). At the end of the plateau period induction of luteolysis by prostaglandin injection results in atresia of an existing dominant follicle followed by formation of a new dominant follicle that ovulates (Lavoir and Fortune, 1990; Fortune et al., 1991). This clearly demonstrates the loss of the inhibitory function of the dominant follicle during the late plateau phase. At this time the dominant follicle is considered to be morphologically dominant (Lavoir and Fortune, 1990; Fortune et al., 1991) and undergoes atresia, thus enabling the emergence of new follicular growth.

It has been suggested that passive and active mechanisms are involved in selection and maintenance of a dominant follicle
(Driancourt, 1991). Increasing the concentration of oestrogen and inhibin in growing follicles inhibits FSH secretion via a negative feedback mechanism (Martin et al., 1988). Dominant follicles possess $\mathrm{LH}$ and FSH receptors and have a low threshold for FSH, allowing them to continue their growth (Findlay, 1986). In growing dominant follicles that are oestrogen-active and histologically healthy with no signs of atresia, the $\alpha$ subunit of the glycoprotein inhibin is predominant. In contrast, regressing dominant follicles are oestrogen-inactive, histologically atretic and the dimeric form of inhibin is prevalent. This dimer is considered as an inhibitor of aromatase activity that reduces the oestrogen:androgen ratio in atretic follicles (Guilbault et al., 1993).

Autocrine or paracrine factors produced by the dominant follicle presumably inhibit the growth of other follicles on both ovaries (Driancourt, 1991). Consequently, superovulatory treatment in the presence of a functionally dominant follicle that was determined by daily ultrasound examinations resulted in reduced ovarian responses in Holstein dairy heifers and Ayrshire cattle (Guilbault et al., 1991; Huhtinen et al., 1992). Our results clearly demonstrate that dairy cows with more than 10 follicles of $3-8 \mathrm{~mm}$ in diameter can be considered to have no dominant follicle at this particular time in midcycle. An animal with a dominant follicle and more than 10 small follicles was never observed. This means that potentially good and poor responders to superovulation and the exclusion of poor responders from superovulatory treatment can be diagnosed by a single ultrasound examination. Other investigators have found that the dominant follicle does not primarily influence the number of small follicles in midcycle but rather their functional status and growth pattern and thereby their ability to respond to superovulatory treatment (Grasso et al., 1989a, b; Roullier et al., 1990).

In the study reported here the number of ova and embryos, and the number of fertilized ova and transferable embryos was significantly higher in animals superovulated in the absence of a dominant follicle compared with animals superovulated in the presence of a dominant follicle at the time of superovulatory 
induction. Obviously, absence of the inhibitory effects of a dominant follicle leads to synchronized growth of a group of subordinate smaller follicles that release fertilizable oocytes and results in higher yields of transferable morulae and blastocysts 7-8 days after artificial insemination. However, elucidation of the underlying physiological events for the increased yields of transferable embryos requires further study. Fertilization rates were different among experiments and between animals with or without a dominant follicle, although semen from bulls with proven fertility had been used in this series of experiments. This could be explained by variations in the interval between the $\mathrm{PGF}_{2 \alpha}$ injection and the endogenous $\mathrm{LH}$ peak, which is known to be shorter in superovulated than in normal animals $(40-50 \mathrm{~h}$ versus 64-82 h) (Barnes et al., 1982; Callesen et al., 1986).

Recovery rates (number of ova and embryos per corpora lutea) were lower in cows with a dominant follicle in all the experiments. It was shown that reduced embryo quality is frequently associated with the early loss of embryos attributed to hormonal imbalances and a disturbed uterine environment (Newcomb et al., 1976; Shea et al., 1976). However, within this context, it should be taken into account that the definition of a dominant follicle, which seems to be of critical importance for achieving a correct diagnosis, can vary among cattle breeds. Guilbault et al. (1991) defined a dominant follicle $>9 \mathrm{~mm}$ in diameter stable for $<4$ days and observed decreased superovulatory responses in the presence of such a defined dominant follicle. In contrast, in our animals the large follicle was defined as dominant for 3 days only. This allowed a consistently accurate diagnosis of its presence or absence. Other investigators have found a more pronounced effect on the superovulatory response in Ayrshire dairy cows when the dominant follicle was defined for 3 days at the plateau phase compared with when it was defined for 4 days (Huhtinen et al., 1992). Presumably, the large follicle progressively loses its dominance at the end of the plateau period of 4 days, resulting in the onset of subordinate small follicular growth and thereby hampering the prediction of the suitability of a cow as an embryo donor.

The ovarian response in animals with a dominant follicle at the time of superovulation induction can be improved by removing the dominant follicle. In this study ultrasound-guided transvaginal aspiration was performed for the first time for this purpose. This procedure allows painless and reliable elimination of the dominant follicle and has been used to collect immature bovine oocytes repeatedly from the same donor (Pieterse ef al., 1991). On the basis of observations that an immediate rise in the concentration of FSH occurs after cauterization of the dominant follicle followed by the emergence of a new follicular wave 2 days later (Adams et al., 1992), the dominant follicle was aspirated 2 days before the onset of superovulatory treatment, which resulted in consistently enhanced superovulatory responses. Attempts have been made to remove the dominant follicle by hormonal methods, such as administration of oestrogen to induce dominant follicle regression (Bo et al., 1991b, 1992), of GnRH to downregulate its gonadotrophin receptors (Savio et al., 1991) or of hCG to luteinize the dominant follicle (Calder and Rajamahendran, 1992), but with no consistent positive effects. Physical removal of the dominant follicle via unilateral ovariectomy or electrocautery has been shown to induce an immediate resumption of small follicle growth (Staigmiller and England, 1982; Ko et al., 1991).
Preliminary experiments have revealed that manual removal of the dominant follicle cannot be consistently accomplished and may lead to adhesions and subsequent impaired fertility (L. Bungartz and $\mathrm{H}$. Niemann, unpublished). Thus, ultrasoundguided transvaginal aspiration seems to be the method of choice for removing a dominant follicle. Experience gained by aspirating immature oocytes from follicles $2-3 \mathrm{~mm}$ in diameter suggests that the procedure can also be performed repeatedly for dominant follicles without impairing fertility (Pieterse et al., 1991; Simon et al., 1993). The early plateau in the second growth phase has been suggested to be the transitional period when the dominant follicle may or may not be morphologically and functionally dominant (Lavoir and Fortune, 1990). The dominant follicle must be removed at a stage when it still possesses functional dominance to obtain the beneficial effects of superovulation.

In our experiments the superovulatory response was similar whether FSH was injected once or twice a day, which is in contrast to previous reports (Chupin and Procureur, 1982, 1983; Walsh et al., 1993). In contrast to other reports (Bo et al., 1991a; Hockley et al., 1992), results from our experiment show that in dairy cows the injection s.c. behind the shoulder led to an increased number of ovulations but the number of transferable embryos was considerably lower compared with multiinjection schedules, while the effect of the dominant follicle was still recognizable. This requires further study. It should be taken into account that the superovulatory response in our experiments was still characterized by a great deal of individual variability, which has hampered the practicability of superovulation and embryo transfer for many years (for review see Seidel, 1981; Armstrong, 1993). Among various other factors, the FSH:LH ratio has been found to affect the bovine superovulatory response and a high contamination with LH has been shown to have detrimental effects (Murphy et al., 1984; Herrler et al., 1991). Folltropin contains low concentrations of LH and has previously been shown to yield acceptable superovulatory responses in both beef and dairy cattle (Mapletoft et al., 1988; Gonzalez et al., 1990; Boland et al., 1991).

In conclusion, results from our experiments strongly suggest that selection of potential donor cows based on the presence or absence of a dominant follicle can significantly contribute to improvements in embryo yields. The detection of the dominant follicle can be achieved with sufficient accuracy by a single ultrasound examination based on the number of small follicles (3-8 $\mathrm{mm}$ in diameter) at the time of superovulatory induction. Ultrasound-guided aspiration of the dominant follicle can rescue potentially poor donors, so that they can undergo superovulatory treatment. This regimen, together with the reduced, less time-consuming FSH injection schedule (four times over 4 days) facilitates the application of superovulation under both experimental and field conditions.

The authors thank F. Elsaesser for providing the progesterone analyses.

\section{References}

Adams GP, Matteri RL, Kastelic JP, Ko JCH and Ginther OJ (1992) Association between surges of follicle-stimulating hormone and the emergence of follicular waves in heifers Joumal of Reproduction and Fertility 94 177-188 
Armstrong DT (1993) Recent advances in superovulation of cattle Theriogenology 39 7-24

Barnes MA, Martinez-Castellano A, Kazmer GW, Wade RJ and Halman RD (1982) Effects of exogenous FSH on estrus, ovulation and endogenous hormone release in dairy cows. Theriogenology $18311-323$

Bo GA, Hockley D, Tribulo H, Jofre F, Tribulo R, Busso N, Barth AD and Mapletoft RJ (1991a) The effect of dose schedule and route of administration on superovulatory response to Folltropin in the cow. Theriogenology 35186 (Abstract)

Bo GA, Pierson RA and Mapletoft RJ (1991b) The effect of estradiol valerate on follicular dynamics and superovulatory response in cows with Synchromate-B implants Theriogenology 36 169-183

Bo GA, Adams GP, Nasser LF, Pierson RA and Mapletoft RJ (1992) Estrogen suppression of the dominant follicle in heifers. Proceedings of the 12th International Congress on Animal Reproduction. The Hague 3 1103-1105

Boland MP, Goulding D and Roche JF (1991) Alternative gonadotropins for superovulation in cattle Theriogenology 35 5-17

Calder M and Rajamahendran R (1992) Does elimination of dominant follicle before superovulation treatment improve ovulation and embryo recovery rates? Proceedings of the 12th International Congress on Animal Reproduction, The Hague 1 196-198

Callesen H, Greve T and Hyttel P (1986) Preovulatory endocrinology and oocyte maturation in superovulated cattle Theriogenology 25 71-86

Chupin D and Procureur R (1982) Use of pituitary FSH to induce superovulation in cattle: effect of injection regime Theriogenology 1481 (Abstract)

Chupin D and Procureur R (1983) Efficiency of pituitary extracts (FSH) for induction of superovulation in cattle Animal Reproduction Science 6 11-23

Driancourt MA (1991) Follicular dynamics in sheep and cattle Theriogenology $3555-79$

Driancourt MA, Thatcher WW, Terqui M and Andrien D (1991) Dynamics of ovarian follicular development in cattle during the estrous cycle, early pregnancy and in response to PMSG Domestic Animal Endocrinology 8 209-221

Elsden RP, Nelson LD and Seidel GE, Jr (1978) Superovulating cows with follicle stimulating hormone and pregnant mares' serum gonadotropin Theriogenology 9 17-26

Findlay JK (1986) The nature of inhibin and its use in the regulation of fertility and diagnosis of infertility Fertility and Sterility 46 770-783

Fortune JE, Sirois J, Turzillo AM and Lavoir M (1991) Follicle selection in domestic ruminants Journal of Reproduction and Fertility Supplement $\mathbf{4 3}$ 187-198

Gonzales A, Lussier JG, Carruthers TD, Murphy BD and Mapletoft RJ (1990) Superovulation of beef heifers with Folltropin: a new FSH preparation containing reduced LH action Theriogenology 33 519-527

Goto K, Ohkutsu S, Nakanishi Y, Ogawa K, Tasaki M, Ohta H, Inohoe S, Takeyama S, Ishii S, Migamoto A, Furusawa T, Umezu M and Masaki J (1988) Endocrine profiles and embryo quality in superovulated Japanese Black Cattle Theriogenology $29615-629$

Grasso F, Guilbault LA, Roy GL, Matton P and Lussier JG (1989a) The influence of the presence of a dominant follicle at the time of initiation of a superovulatory treatment in the superovulatory response in cattle Theriogenology 31199 (Abstract)

Grasso F, Guilbault LA, Roy GLK and Lussier JG (1989b) Ultrasonographic determination of ovarian follicular development in superovulated heifers with FSH-P at the beginning of the estrous cycle Theriogenology 31 $1209-1220$

Gray BW, Cartee RE, Stringfellow DA, Riddell MG and Wright JC (1992) The effects of FSH priming and dominant follicular regression on the superovulatory response of cattle Theriogenology 37 631-639

Guilbault LA, Grasso F, Lussier JG, Roullier P and Matton P (1991) Decreased superovulatory responses in heifers superovulated in the presence of a dominant follicle Journal of Reproduction and Fertility 91 81-89

Guilbault LA, Roullier P, Matton P, Glencross RG, Beard A) and Knight PG (1993) Relationship between the level of atresia and inhibin contents ( $\alpha$ subunit and $\alpha-\beta$ dimer) in morphologically dominant follicles during their growing and regressing phases of development in cattle Biology of Reproduction 48 268-276

Herrler A, Elsaesser F and Niemann H (1990) Rapid milk progesterone assay as a tool for the selection of potential donor cows prior to superovulation Theriogenology 33 415-422

Herrler A, Elsaesser F, Parvizi N and Niemann H (1991) Superovulation of dairy cows with purified FSH supplemented with defined amounts of LH Theriogenology 35 633-643
Hockley DK, Bo GA, Palasz AT, Del Campo MR and Mapletoft RJ (1992) Superovulation with a single subcutaneous injection of Folltropin in the cow: effect of dose and site of injection Theriogenology 37224 (Abstract)

Huhtinen M, Raino V, Aalto J, Bredbacka P and Maki-Tanila A (1992) Increased ovarian responses in the absence of a dominant follicle in superovulated cows Theriogenology 37 457-463

Ireland JJ and Roche JF (1987) Hypothesis regarding the development of dominant follicles during a bovine estrous cycle. In Follicular Growth and Ovulation in Farm Animals pp 1-18 Ed. JF Roche and DO Callaghan. Martinus Nijhoff Publishers, Dordrecht

Kastelic JP, Knopf L and Ginther OJ (1990) Effect of day of prostaglandin $F_{2 \alpha}$ treatment on selection and development of the ovulatory follicle in heifers Animal Reproduction Science 23 169-180

Knopf L, Kastelic JP, Schallenberger E and Ginther OJ (1989) Ovarian follicular dynamics in heifers: test of two-wave hypothesis by ultrasonically monitoring individual follicles Domestic Animal Endocrinology 6 111-119

Ko JCH, Kastelic JP, Del Campo MR and Ginther OJ (1991) Effects of a dominant follicle on ovarian follicular dynamics during the oestrous cycle in heifers Journal of Reproduction and Fertility 91 511-519

Lavoir M and Fortune JE (1990) Follicular dynamics in heifers after injection of $\mathrm{PGF}_{2 a}$ during the first wave of follicular development Theriogenology 33270 (Abstract)

Lussier JG and Carruthers TD (1989) Endocrine and superovulatory responses in heifers pretreated with FSH or bovine follicular fluid Theriogenology 31 779-794

Mapletoft RJ, Gonzalez A, Lussier JG, Murphy BD and Carruthers TD (1988) Superovulation of beef heifers with Folltropin ${ }^{(\mathbb{R})}$ or FSH-P Theriogenology 29 274 (Abstract)

Martin GB, Price CA, Thiery JC and Webb R (1988) Interactions between inhibin, oestradiol and progesterone in the control of gonadotropin secretion in the ewe Journal of Reproduction and Fertility 87 319-328

Murphy BD, Mapletoft RJ, Manns J and Humphrey WD (1984) Variability in gonadotropin preparations as a factor in the superovulatory response Theriogenology 21 117-125

Newcomb RE, Rowson LEA and Trounson AO (1976) The entry of superovulated eggs into the uterus. In Egg Transfer in Cattle pp 1-13 Ed. LEA Rowson. EEC Seminar, Commission of the European Communities, EUR 5491, Luxemburg

Niemann H (1986) Möglichkeiten und Grenzen des Embryotransfers bei landwirtschaftlichen Nutztieren Tierärztliche Umschau 41 625-633

Pierson RA and Ginther OJ (1988) Follicular populations during the estrous cycle in heifers. III Time of selection of the ovulatory follicle Animal Reproduction Science 16 81-95

Pieterse MC, Vos PLAM, Kruip TAM, Wurth YA, van Beneden TH, Willemse AH and Taverne MAM (1991) Transvaginal ultrasound guided follicular aspiration of bovine oocytes Theriogenology 35 857-862

Rouillier P, Matton P, Guilbault L, Grasso F and Lussier JG (1990) Influence of a dominant follicle atresia and estradiol release by ovarian follicles during superovulation in cattle Theriogenology 33313 (Abstract)

Savio JD, Keenan L, Boland MP and Roche JF (1988) Pattern of growth of dominant follicles during the oestrous cycle of heifers Journal of Reproduction and Fertility 83 663-671

Savio JD, Boland MP and Roche JF (1990a) Development of dominant follicles and length of ovarian cycles in postpartum dairy cows Joumal of Reproduction and Fertility 88 581-591

Savio ID, Boland MP, Hynes N, Mattiacci MR and Roche JF (1990b) Will the first dominant follicle of the cycle of heifers ovulate following luteolysis on day 7? Theriogenology 33 677-688

Savio JD, Bongers H, Drost M, Lucy MC and Thatcher WW (1991) Follicular dynamics and superovulatory response in holstein cows treated with FSH-P in different endocrine states Theriogenology 35 915-929

Seidel GE, Jr (1981) Superovulation and embryo transfer in cattle Science 211 $351-358$

Shea BF, Hines DJ, Lightfoot DE, Ollis GW and Olson SM (1976) The transfer of bovine embryos. In Egg Transfer in Cattle pp 145-152 Ed. LEA Rowson, EEC Seminar, Commission of the European Communities, EUR 5491, Luxemburg

Simon L, Bungartz L, Rath D and Niemann H (1993) Repeated bovine oocyte collection by means of a permanently rinsed ultrasound guided aspiration unit Theriogenology 39312 (Abstract)

Sirois J and Fortune JE (1988) Ovarian follicular dynamics during the estrus cycle in heifers monitored by real-time ultrasonography Biology of Reproduction $39308-317$ 
Staigmiller RB and England BG (1982) Folliculogenesis in the bovine Theriogenology 17 42-52

Van de Wiel DFM and Koops W (1986) Development and validation of an immunoassay for progesterone in bovine milk or blood plasma Animal Reproduction Science 10 201-213

Walsh JH, Montovani R, Duby RT, Overstrom EW, Dobrinsky JR, Enright WJ, Roche JF and Boland MP (1993) The effects of once or twice daily injections of p-FSH on the superovulatory response in heifers Theriogenology 40 $313-322$
Wilson JW, Jones AL and Miller DR (1990) Influence of a dominant follicle on the superovulatory response Theriogenology 33349 (Abstract)

Yadav MC, Walton JS and Leslie KE (1986) Plasma concentration of luteinizing hormone and progesterone during superovulation of dairy cows using follicle stimulating hormone or pregnant mares' serum gonadotropin Theriogenology 26 523-540 